\title{
Indicators of Tribal Identity in Aotearoa/New Zealand
}

I belong to Tūhoe, a tribal group that is situated in the centre east of the North Island of Aotearoa/New Zealand. Tūhoe are situated in a very mountainous and bush clad area and was one of the last tribal groups to make contact with Pākehā. As a consequence, there are some things that we have been advantaged by. One of those things is that we have retained the language. We have also been able to maintain some of our traditions and history because our kinship structure is largely made up of family groups that have been able to keep together, despite the geographic nature of our area. Furthermore, there are factors that determined how often we met. One of these is religion. The religious sect that our people embraced was the Ringatu faith that was introduced into our district by Te Kooti. Arikirangi Te Turuki Te Kooti was much maligned in the history of Aotearoa/New Zealand because of certain acts he undertook with his people during his flight from government forces and the creation of a centre of religion for his followers.

My name when I was young was Jimmy. My father called me Jimmy because my father was a Manxman, a person from the Isle of Man in the Irish Sea. He came to New Zealand as a baby in the 1800s and he grew up here and eventually met my mother, who was a full Māori. I was named Jimmy because my Manx grandfather was called James. I am telling you these details because whakapapa, or genealogy, is important when talking about one's identity. I raise the matter of my father because I have assumed a greater Tūhoe identity than I have a Pākehā identity. That does not demean my feelings towards my father, but it happens that I assumed an identity quite different from his because I grew up amongst my mother's people. I was called Jimmy but my Māori relatives called me Timi, a transliteration of Jimmy. I was known as Timi for a

Formerly the professor of the Department of Māori at The University of Waikato, Wharehuia Milroy is now a member of the Waitangi Tribunal and Te Panekiretanga o Te Reo, which aims to promote excellence in the Māori language. He was awarded a QSO in 2003 and an Honorary Doctorate from The University of Waikato in 2005. 
long time, although I knew my other name was Wharehuia. At that time I didn't know where Wharehuia originated. I left my home district to further my education. I moved out of the district to complete my secondary school education in Rotorua. After that I moved to various parts of the country, ending up in the Department of Māori Affairs. From there I went up to the University of Auckland.

While I was at university John Te Rangiāniwaniwa Rangihau and Tìmoti Kāretu were at The University of Waikato. It was while I was at Auckland that I was enticed by them to join the University of Waikato staff. It was at this time that John Rangihau said, 'Jimmy goes out the window, Wharehuia comes in.' Those of you who know Dr Timoti Kāretu, will also know that Tìmoti would give everyone a Māori name and Jimmy was not good enough, but Wharehuia would do. Thus I have assumed that name and remained Wharehuia to this time. I am glad to say that I have a grandson named Wharehuia.

I raise this, and the issue of my choice of identity, because I grew up in a community whose traditions, rituals and language I assumed as part of my identity. I did not think of myself as half Pākehā. As children we went swimming naked in the local river. When I went to dive in the water, someone laughed at me and said, 'Ha, ha, you are a tou wherowhero.' Tou wherowhero means 'pink bum'. That really hurt me because up to then, I just thought of myself as another whānau member, another hapū person - another person of Tūhoe identity. As a result, I learnt how to fight and stand up for myself. I was determined to prove to everyone that I was Māori. I mention this because these are the difficulties that some of our own young people face today. It was such a shock to be made aware that I was different from the other playmates. This was during the Second World War. Milroy was a Pākehā name. Some accused me of being German, but I have no German blood in me. Those were the things that used to be thrown at me when I was a young child.

It was at that time that I became determined to bury myself in everything that was of a Tūhoe nature. I would sit next to the old koroua (elderly men) and kuia (elderly women) of our family, of our sub-tribe and of our tribal groups, listening to their conversations. At the early morning and night church services in the meeting house, I would sit and listen to the rituals, picking up the language and taking cues from the way people behaved in those contexts. As I grew older and able 
to understand certain things about the rites of passage in a variety of situations, I absorbed some knowledge that was to become valuable later.

As a consequence of John Rangihau's concerns about Tūhoe young people moving into the urban areas and beginning to lose their identity, he began to set up wānanga. Modernity was beginning to assume a large part of their personalities. A new type of personality was subsuming the tribal self. The fa'asammoa attitude was the kind of attitude that was vested in us when we were young - you must not lose your Tūhoetanga. But amongst my own peer groups, you had to fight for your identity, to be accepted into a group. When you are a half-caste it is twice as hard. If you are different it is very hard. If you are different from the others it is very difficult to influence them because your personality is subordinated by a whole host of pressures that operate on you. Within that whānau group itself people are reminding you of different sorts of things. But one thing which kept my feet on the ground was the fact that I could whakapapa, I could trace my genealogy right back to the beginning of time. I learnt my whakapapa, right from when there was te kore, the nothingness, through all those different stages of the development of the evolution of this world until we human beings came to occupy this earth. I could trace my whakapapa back right from that time to the present. That is a huge advantage when you get into a debate with people who are questioning your heritage. I got rid of the accusation that I was German. The Pākehā part of me was still there because my father was still alive and you cannot ignore that there is another part of you. That Pākehā identity only raised itself when you had to defend your actions against your own peers. By that I mean if you rose above mediocrity there was always someone there to pull you back again to the same level they were at. This allowed you to keep belonging to the group. One has a strong desire to remain part of the group, but there is this other urge to strive for something different. These are the kind of conflicts and tensions that are faced by a Tūhoe individual and what I faced when I was living with Tūhoe groups.

I am first and foremost Tūhoe, secondly I am a Māori, and thirdly I am a Pākehā. I identify as Tūhoe. I cannot speak on behalf of any other tribal group. I speak from the perspective of my own people. So when I am talking to you, I am talking to you as a Tūhoe and what I understand to be Tūhoe means. 
There are three, perhaps four, key words I wish to focus on. I have already mentioned whakapapa, or genealogy. Genealogy in terms of the Tūhoe identity becomes quite important because Tùhoe, the man, was the third of three brothers. The eldest was Ueimua; the second eldest was Tānemoeahi; and the third brother was Tūhoe. They all had families and occupied different land areas. The eldest brother lived out towards the coast in Whakatāne. The two younger brothers lived inland. One day there was a debate that ended up in bad blood and in the end the brothers fought against one another. One of the traditions of the Māori is that if you are to assume the mana of leadership there are certain things you have to do. In this case, Tūhoe, being the youngest, thought he would kill his eldest brother, which he succeeded in doing, but that in itself was not sufficient. Tradition required that you had to cut out the heart and eat it and that way you assume the mana. If you take that historical account, it is then transmitted through the ages, down through the different tribal generational groups and you are descended from a person who assumed authority, and he is the eponymous ancestor of your tribal group. You have an obligation, whether you like it or not, to maintain that leadership mana because you are a descendant of that person. Tūhoe became the name of our tribal group. Having that name is insufficient in itself. You, as a tribal group, can talk about yourselves as being Tūhoe. But it carries no weight unless other tribal groups recognise certain characteristics and traits that are exhibited by you. Let me talk about Pou Temara. Pou Temara is chosen by different tribal groups to act as a tohunga in these ritual ceremonies. He is a Tūhoe. He is a role model. Likewise Dr Tìmoti Kāretu is an expert in Māori language. He is another Tūhoe. Then there is Hirini Melbourne, who spent much of his final 20 years of life researching the flutes and musical instruments of the Māori and composing his own songs and those songs now sung by Kōhanga Reo and Kura Kaupapa throughout this nation.

Then there is someone younger like Whirimako Black, who sings our old mōteatea, old traditional songs, with a modern style. The sentiments are still there, but the sounds are modern sounds that young people can relate to easily. Those songs still serve the same purposes as when they were first composed many, many years ago, sometimes hundreds of years ago. They are still telling a story which is ages old and which reinforces the idea of a Tūhoe person. She has taken a 
number of old songs and some of us did not quite like it. I was one of those ones that did not like what she did. But now, I can appreciate it serves another purpose. Young people have to adapt to the contexts that face them.

With my whakapapa I have no fear of stepping on my marae and speaking where I think I have an appropriate and proper right to do so. There are many marae in our area, and we are not a large tribal group, but we have been blessed by geographical isolation and by having leaders who have a vision for the future and what was happening outside our district. They have sought the support of the people to prevent changes being made at too great a pace. That is the first thing about whakapapa. These people ensured that most of our young folk had some rudimentary knowledge of how to relate to each other. In the immediate family group you know each other, but when you extend to the other districts of your tribal territory where your other kinsfolk are living who you do not meet so often, it is important to maintain contact with them. You need to have some knowledge of how you are related to them. Younger members of Tūhoe often address me as 'Uncle'. I know when they use the word 'Uncle', they are not using it in terms of the Pākehā meaning of the word. 'Uncle' is loaded with all the obligatory things required of a Tūhoe person. The term of address will also be a reminder of the Tūhoe kinship relationship. There are layers and meanings that are associated with the term 'Uncle'. Likewise 'Pāpā' and 'Māmā', as terms of address for older men and women, may be used, not in the sense of father or mother, but in the sense of an elder who can be approached for assistance or advice. This is setting behavioural levels, how to behave in certain contexts. One hears children in the Kura Kaupapa using the words 'Matua' and 'Whaea', literally 'Father' and 'Mother', but using them in a much broader sense of identifying with their seniority.

Whakapapa is a link between the past and the present. It tells me who I am descended from and it tells me to whom I am related at the present time. I am related to a number of individuals within a family group; I am related to the extended whānau group; I am related to the hapū, and then to the much wider iwi group. Iwi is the large tribal group. It is my link between my collective group and the land. Land is a very important to part of this identity. Recent studies show that people who have been alienated from their land suffer a whole host of mental illnesses or psychological disorders because 
they suffer from an identity crisis. Thus there is a strong link through ones whakapapa with the collective group and the land. For Tūhoe, there is a connection through religion between the people and God. Tūhoe have assumed either the Ringatū religion or one of the Christian religions. There is also a connection of whakapapa with one's history and traditions. Past events were not all positive and there were also omissions by one's people. There are lessons to be learnt from these. There are negative and positive aspects and these are recalled from time to time to reinforce one's identity. Tìmoti Kāretu and Pou Temara sometimes say to me, 'Te tohu takoto o Ngāi Te Riu.' This is because I belong also to this hapū called Ngāi Te Riu and therefore am connected to te tohu takoto o Ngāi Te Riu. Tūhoe oral tradition states that Ngāi Te Riu remained neutral in a very difficult situation, a conflict with Te Arawa, and did not take sides. So that was an omission on the part of my hapū, Ngāi Te Riu. I suppose if I want to ignore that, I will go to my other hapū, Ngāti Kōura, and sit there while this debate goes on about Ngāi Te Riu. On the other hand, there was also a positive that resulted from that negative action in that no one got hurt, no one got killed, except Tìmoti's people. So identity involves the transmission of behaviour patterns that characterised Tūhoe through its communities and social contact.

John Rangiāniwaniwa Rangihau was a person with whom we were intimately associated. He had a vision that if he did not do something for the young Tūhoe people, they would lose their identity. So he decided in the early 1970s to call us together for what we call wānanga, schools of learning. The idea was to introduce us to our elders and let us have an exchange and a discussion on our roles and their roles to see where changes could be made, and where changes could not be made. Tühoe is a very conservative tribe, very reluctant to make changes, but that is where its strength lies. If you make too many changes you lose an essential part of your being, you are no longer a Tūhoe, you are someone else. It sets us apart from everyone else because there are things about our makeup that are unique to our tribal group.

We have linguistic expressions that are peculiar to ourselves and we use those expressions amongst ourselves. Their use reinforces our unique relationship. Amongst one's own people one knows what is appropriate without creating difficulties and without creating a conflict. One also knows how to start a conflict. These are extended family behavioural 
patterns. I am from Ruātoki, Tīmoti is from Waikaremoana, located about 100 kilometres apart, but we can go to Waikaremoana and use the same expressions and know that we would understand the nuances of the colloquial language we are using. But if we stepped just a few kilometres down the road into the Ngāti Kahungunu tribal area, we may find a different sense being applied to the same expressions. Language becomes a very important tribal identifier.

When we met in the Tūhoe wānanga, Rangihau always expressed sets of values that he wanted young Tūhoe to assume. Later on, we were required to take on the responsibilities of leadership. We were to assume the guardianship of all those values, and if we did not do our job then he had failed and we had failed. He was very focused, single-minded person and his word was law. One of the first things he taught us was humility and respect, to be humble. This is whakaiti, being humble and using deferring terms, in terms of your relationships. The key word I guess in our identity is the quality of the relationships that we develop with each other. Humility, or whakaiti, was one trait, respect and service to others was another. We become quite emotional about what our ancestors have bequeathed. One does not want to lose those things and that becomes part of our behavioural patterns. So it is putting others before oneself. We should not be kaiponu; we should not keep things to ourselves that should be shared, including knowledge. That is what Rangihau taught us. If I hear the tribal expression, 'Tūhoe moumou kai, moumou taonga, moumou tangata', it does not mean in the literal sense that we are wasters of food, wasters of property and wasters of people. Rather, it reflects that that it is how we serve others, even to the point where one gives so much that in doing so one personally suffers so that others can benefit. That is another part of our Tūhoe identity, the ideal Tūhoe identity. It is hard to keep to these ideals and values because the modern world is beginning, by stealth, to take away that tribal identity that we have, that whānau identity that we have, that Ngāti Kōura or Ngāi Te Riu or Tūhoe identity.

Tūhoe have tried to maintain most of their old traditional songs, to perform them as often as possible and in the appropriate contexts because they have an application to the situation and contexts in which we are involved. It is difficult now for the young generation to adhere to tradition. In the marae context, and even in one's own personal behaviour, it is 
expected that Tūhoe will adhere to these traditions. As an example, one will find times that we of Tūhoe will not eat before visitors have been fed. This is something that is instilled in us from a very young age. Do not be seen eating with your visitors. If you do that, you are hurrying them along because you want to eat the supplies up. Let your visitors enjoy their meal first. Service to others before oneself. There is a Tūhoe group at Maungapōhatu who will never be seen eating with the visitors. It is always the visitors first and foremost. The locals will go away and eat in the dark, in a house entirely separate from the marae. They maintain this custom.

The deck of cards reflects this practice. The suits were painted on the house of Rua Kēnana, the prophet. The heart is the highest valued suit and represents those people who come from outside the district. Long-distant travellers are given the most important position in the visitor's hierarchy. The next highest valued card is the diamond, represented by the tribal groups that are in close proximity to their tribal area. The next highest valued suit is the club that represents the hapu $\overline{\text {, the }}$ tribal groupings outside the host marae. The people of the host marae assume the value of the spade, the lowest valued suit. Their role is to serve all the others. It is these sorts of behaviours our elders instilled in us. One will find that we are always reluctant to sit at the food tables because we have grown used to waiting for others to eat first. It is only when someone says, 'Come on, come on, join us,' that we will do so.

Consistency of behaviour and this is where I will tell you about John Rangihau. I was involved in a debate with someone from another tribal group. We were just having a quiet beer in a bar full of people and the discussion progressed into tribal politics - a dangerous topic! The result was that we started arguing. Little did I know that Rangihau was in another room. Somebody who knew that he was there told him that I was in this argument. He came in the door and yelled out at the top of his voice saying, 'I told you, I told you, humility!' (I could not find a hole big enough to hide in; my face went red and he took me aside and reprimanded me. One learns those lessons because that is how a Tūhoe is supposed to act. Do not become involved in arguments; do not be drawn into something unless it is with one's own people, one's own family group. If one becomes involved in a discussion with someone else, use the appropriate context. When one starts discussing tribal matters in a public place like a pub, that is not an appropriate forum. That sort of situation and 
experience conditions you to act in particular ways. There is a requirement to know who you are. There are different types of Tūhoe identities now and when I talk about a Tūhoe identity I always think of my own generation as real Tūhoe. But when I compare my generation with our predecessors we are mere shadows of Tūhoe because we have not assumed all those things they had, even their knowledge; we have moved into a different world. But what we hope is that there are some things that are consistently being maintained by the younger generation as we engage with them and talk about who they are and what they are.

There is this thing called 'kanohi kitea', or 'mata kitea', which places a host of obligations on Tūhoe tribal members. Let us say you are in Auckland and your relative dies in the Bay of Plenty, where we live, and during the course of the rites of passage you were not seen, you did not come to share the grief of the family. These words are used kanohi (face) kitea (seen), or mata kitea, in relation to your absence. Both mean the same thing, the 'seen face'. If your face is not seen the questions are asked, 'Where were you? Why did you not turn up? Why weren't you here when we needed you at a very important time?' Such questions condition one into a particular type of behaviour. These questions are used to modify behaviour, especially by one's own whānau group.

Modernity has increased the number of choices that individuals have to make. As a result, social ties can begin to weaken. People become more self-centred. Native languages focus on the human part of our world. If you look at modern English, it is full of technical terms. It has de-humanised us. Tribal people have a Sisyphean task to push the rock up the slippery slope because our identities are being affected by what we engaged in. I feel for the Cree, I feel for the Hawaiians who are trying so hard to keep that part of themselves, their language, intact so that this erosion is arrested to the point where at least they can develop strategies in order to maintain their languages. Once the language is lost, so is the wairua; the spirit has died because one has nothing else to call upon.

Tribal identity, or the identity of a nation, defines and locates an individual within the larger group. It even locates one with nature. It provides a framework in which humans can be depended on to interact with each other and to interact with the natural environment. That is what I think my Tūhoe identity does for me. Our tribe has defined our relationships. 
As an example, there are some expressions of what I think constitute the kind of language we may use to one another.

Tribal aphorisms, tribal sayings, will help illustrate what a Tūhoe identity is. If I say, 'He momo', it could be sarcastic or it could be complimentary. If someone acts in a particular way, possibly in a manner not acceptable, I would say, 'He momo.' That means that trait comes down through that family line that is what they are like. Or, I will say, 'He momo', meaning that she possesses those particular admirable talents that come through her family line. 'He momo' depends on the inflexion of one's voice as to which 'momo' is meant, an admired quality, or the opposite. We use that expression a lot in Tūhoe to determine whether you criticise or elevate a person.

This saying applies to one of Pou Temara's hapū: 'te ara a Tāne, he uri pūkākā'. If I translate this into English it means 'the impatient penis of men'. There is a hapū group within Tūhoe to whom this is applied. It identifies the hapu as soon as one uses the expression. It identifies a person within that particular group. The members of the hapu behave in a particular way, especially when aged between 17 and 25. After that age they are 'mature' and the behaviour is modified. This is the power of language, how language is important to identity and how we use it to identify ourselves.

Let me go back to that question of humility. I notice with Tūhoe groups performing in national kapa haka competitions that they have forsaken this whakaiti thing because when they have done well they have stood up and performed the haka, thus exhibiting arrogant behaviour. We have this expression, 'mā roto rā e kata' which is 'let the inside of you smile, but be humble in front of the general public until you go home where you can show your joy. Consider the feelings of the others and be humble'.

This is the power of the word to modify someone's behaviour. The language must not be lost; your languages must not be lost. 